\title{
OPTIMASI WAKTU PEMOTONGAN GATE MASTER CYLINDER FRONT KVYG DENGAN SIMULASI DESAIN FIXTURE MENGGUNAKAN SOLIDWORKS MOTION ANALYSIS
}

\author{
Meda Deni Kristanto, Suyadi, Bambang Tjahjono \\ Jurusan Teknik Mesin .Politeknik Negeri Semarang \\ Jl. Prof. Soedarto, SH, Tembalang, Semarang 50275 \\ Email:
}

\begin{abstract}
Abstrak
Permasalahan di departemen Gravity Die Casting pada line potong gate Master Cylinder masih dengan proses pemotongan yang manual yaitu metode potong yang masih di pegang tangan dan setelah memotong 40 pcs atau 1 box mesin di matikan untuk menata part di rak treatment sehingga terdapat lost time yang berlebih di proses tersebut. Tujuan dari penelitian ini adalah Melakukan optimasi waktu pemotongan gate master cylinder front KVYG dengan membuat simulasi Desain Fixture menggunakan Solidworks Motion Analysis dengan mekanisme otomasi pneumatik, untuk mereduksi terjadinya lost time yang dapat meningkatkan produktifiktas dan mempercepat cycle time proses pemotongan gate master cylinder front KVYG. Metode perancangan yang digunakan adalah metode perancangan Archer yang terdiri dari Programing, Data collection, Analysis, Synthesis, Development dan Communication. Pengujian dilakukan dengan membuat beberapa alternatif desain dan parameter-parameter yang berbeda yang selanjutnya dapat di analisis efisiensi desain dan menjadi validasi pengujian yang dilakukan. Hasil yang di peroleh yaitu cycle time pemotongan dapat dipersingkat dari 15 detik/pcs menjadi 10,5 detik/pcs. Gaya untuk memotong part MC type KVYG front sebesar 92,3 x $10^{3}[N]$ dan terdapat 2 pneumatik yaitu pneumatik cutting yang berdiameter 13,6 [mm] serta pneumatik tuas pengungkit (take out) berdiameter 10,3 [mm].
\end{abstract}

Kata Kunci : "Optimasi”, "Desain fixture”, "Solidworks motion analysis”.

\section{Pendahuluan}

Gravity Die Casting merupakan salah satu proses produksi pertama yang berada pada PT. Chemco Harapan Nusantara Plant 1 cikarang, ada beberapa spare part yang diproduksi menggunakan metode gravity die casting. Gravity die casting adalah metode pengecoran yang kompetitif ketika kuantitas produksi relatif kecil atau ketika perlakuan panas diperlukan untuk meningkatkan sifat mekanik. (Mishra, et al., 2017). PT. Chemco Harapan Nusantara dituntut untuk menghasilkan kualitas produk yang stabil, banyak parameter yang perlu diperhatikan dalam menjaga kestabilan kualitas tersebut, dimulai dari komposisi material, proses pengolahan material, proses casting itu sendiri hingga proses treatment sampai proses quality yang harus tetap terjaga kualitasnya baik secara visual maupun secara sifat mekaniknya untuk menjaga kepuasan customer. Syarat yang ditetapkan oleh customer harus Zero defect, maka PT. Chemco Harapan Nusantara terus berupaya dengan melakukan monitoring secara berkala dan ketat untuk setiap produknya agar selalu stabil dalam hal kualitas. Penjagaan kualitas yang stabil tentunya menemui beberapa permasalahan yang ada mulai dari cost produksi hingga biaya yang timbul akibat produk NG (Not Good) atau cacat karena beberapa kesalahan seperti kesalahan operator, metode pengerjaan atau proses produksi maupun life time dari peralatan yang digunakan.

Selain dari segi kualitas PT. Chemco Harapan Nusantara juga dituntut dalam hal kuantitas produk, sehingga manajemen harus mulai berinovasi dengan Otomatisasi produksi tanpa mengorbankan tenaga kerja yang ada. Automation (otomasi) adalah suatu teknologi dimana proses atau prosedur dilakukan tanpa atau dengan bantuan manuasia (Grover, 2002). Khusus untuk proses potong pada gate master cylinder type $K V Y G$ proses pemotongan masih tergolong manual yaitu dengan memegang dangan tangan saat proses pemotongan dan proses ini memakan waktu yang relatif lama karena terjadinya lost time. Data yang diperoleh menunjukkan untuk waktu pemotongan 40 pcs diperlukan waktu rata-rata 10 menit dan 
terdapat lost time proses 2,5 menit per 40 pcs sehingga kapasitas produksi kurang optimal yaitu $772 \mathrm{pcs} / \mathrm{shift}$ dari yang di targetkan yaitu 1200pcs/shift. Lost time yang terjadi di proses ini merupakan salah satu akibat dari pemotongan gate master cylinder yang kurang efisien maka dengan merencanakan desain alat bantu pemotongan yang dapat menggantikan proses pemotongan sebelumnya. Hal yang melatarbelakangi pembahasan permasalahan tersebut karena adanya beberapa hal yang perlu adanya optimasi di proses potong khususnya proses potong Gate Master Cylinder front KVYG yang masih manual seperti pada gambar 1.1.

Kekurangan pada proses potong manual yaitu:

1. Terjadinya lost time proses penataan yang mengakibatkan proses potong terhenti berbanding lurus dengan waktu penataan.

2. Kurang adanya safety pada operator.

3. Terjadinya lost time proses penataan yang mengakibatkan proses potong terhenti berbanding lurus dengan waktu penataan.

4. Kurangnya kualitas potong yang di hasilkan (sering kali operator memotong gate tidak tegak lurus dan terjadi over cutting) hal ini sering terjadi produk NG.

5. Kurangnya produktivitas hasil potong sesuai data ada.

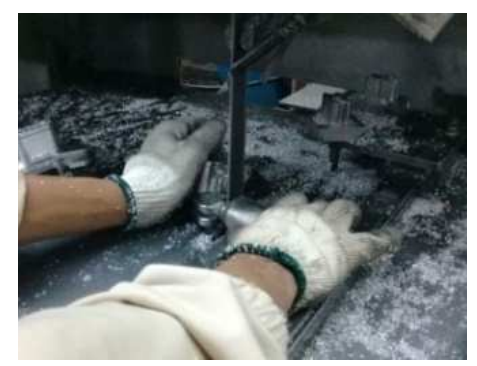

\section{Gambar 1. Proses Potong Manual Gate MC KVYG front}

Simulasi Desain Fixture pemotongan gate master cylinder front KVYG menggunakan Solidworks Motion Analysis diharapakan dapat menjadi salah satu solusi perancangan alat bantu pemotongan gate master cylinder front $K V Y G$ untuk meminimalisir atau menghilangkan lost time yang dapat meningkatkan produktifiktas dan mempercepat cycle time proses. Cycle time sebelumnya yang kurang efektif karena proses pemotongan gate master cylinder front $K V Y G$ masih dilakukan manual dengan tangan.

Fixture adalah Alat mekanis yang kuat dan kaku yang menempel pada mesin dan memungkinkan stok untuk meluncur saat dipegang dengan kuat memungkinkan penempatan, penunjang dan penjepitan yang mudah, cepat dan konsisten akurat, kosong terhadap cutting tool dan hasil pemesinan yang lebih cepat dan akurat dengan kualitas yang konsisten, kemampuan fungsional (Abouhenidi, 2014). Prinsip dasar dari alat bantu pemoto ngan gate master cylinder front $K V Y G$ ini menggunakan prinsip linier recriprocating dengan menggunakan lintasan linier guideway untuk lintasan maju mundurnya. Fixture di gerakkan oleh Pneumatik yang ada di pangkal proses potong, pneumantik mendapat supply dari udara yang sudah ada di sub potong. Semiautomatic di dapatkan dari pemasangan limit switch yang ada di awal dan akhir proses maju mundur dan proses kerja di awali dengan menekan tombol On. Mekanisme semi-automatic yang akan digunakan mampu meningkatakan efisiensi waktu pemotongan gate master cylinder front $K V Y G$ dengan cycle time lebih cepat, karena mekanisme seperti ini dapat bekerja secara terus-menerus atau kontinyu. Tujuan dari penelitian ini adalah melakukan optimasi waktu pemotongan gate master cylinder front KVYG dengan membuat simulasi Desain Fixture menggunakan Solidworks Motion Analysis dengan mekanisme otomasi pneumatik, untuk meminimasi terjadinya lost time yang dapat meningkatkan produktifiktas dan mempercepat cycle time proses pemotongan gate master cylinder front KVYG.

\section{Metode Penelitian}

Fishbone Diagram dikenal sebagai Diagram Ishikawa. Itu mendapat nama dari bentuknya, yang dalam bentuk kerangka ikan. Itu dibuat oleh Profesor Kaoru Ishikawa, yang memelopori proses manajemen mutu di Kawasaki Shipyards pada 1960-an. Diagram 
tulang ikan juga dikenal sebagai diagram sebab-akibat. Ini membantu untuk menunjukkan korelasi antara efek dan beberapa penyebab yang terjadi. Diagram tulang ikan menunjukkan kemungkinan penyebab peristiwa tertentu atau masalah. Ini juga menggambarkan kemungkinan penyebab masalah tertentu dengan menyortir dan menghubungkan setiap penyebab menggunakan skema klasifikasi. Secara umum, ini adalah analisis dari dampak yang menyebabkan hasil tertentu mengamati fenomena (Dimas, 2016).

Berdasarkan analisis penyebab masalah tertinggi dapat diketahui dengan adanya langkah-langkah perbaikan menggunakan aspek-aspek cause \& effect diagram (Fish Bone Diagram), sebagai berikut;

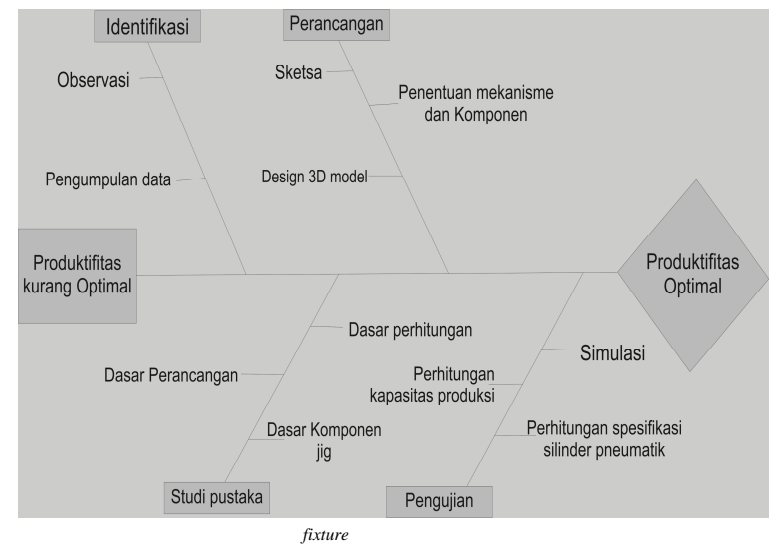

Gambar 2 Fishbone Diagram

\subsection{Identifikasi}

Proses identifikasi mecangkup permasalahan yang terjadi pada line produksi khususnya sub potong Master Cylinder front type $K V Y G$, pengambilan beberapa data seperti data produksi part Master Cylinder front type $K V Y G$, cycle time proses potong, spesifikasi material, spesifikasi mesin potong dan sketsa part Master Cylinder front type KVYG yang dilakukan melalui beberapa tahapan seperti dibawah ini:

a. Observasi

b. Pengupulan data

\subsection{Studi pustaka}

Mencari jurnal - jurnal dasar perhitungan untuk menunjang analisa yang dilakukan dan mendukung penyelesaian masalah yang ada.
Tahapan ini yang menjadi dasar dan acuan penelitian ini dengan mencari literaturliteratur seperti yang ada dibawah ini:
a. Dasar perancangan
b. Dasar komponen fixture
c. Dasar perhitungan

\subsection{Perancangan}

Proses Perancangan merupakan aktivitas berupa gambaran mengenai perancanganperancangan dalam pembuatan fixture pemotongan gate Master cylinder front $K V Y G$ dengan meliputi tahapan-tahapan yang ada dibawah ini:
a. Sketsa
b. Penentuan mekanisme dan komponen
c. 3D model

\subsection{Pengujian}

Proses Pengujian merupakan salah satu proses terakhir yang ada pada penelitian ini, pengujian ini mengacu pada perhitunganperhitungan yang sudah dilakukan dan simulasi yang sudah di sesuai. Pengujian tersebut meliputi:

a. Simulasi

b. Perhitungan kapasitas produksi

c. Perhitungan spesifikasi silinder pneumatik Pengujian dilakukan dengan simulasi solidworks dengan input data waktu yang di peroleh dari estimasi proses potong sebelumnya yaitu menghilangkan proses penataan pada proses yang menjadi sumber lost time sebesar 5 detik/pcs dan mengahasilkan waktu proses keseluruhan 15 detik/pcs, hal ini menjadi acuan dalam input waktu proses improvment pada solidworks motion analysis. Output yang dihasilkan pada simulasi ini berupa waktu yang yang sudah di kalkulasi setiap proses menjadi 10 detik/pcs. Pengujian ini menjadi suatu validitas dari perancangan fixture pemotongan gate Master Cylinder front $K V Y G$.

\subsection{Flow Procces Penelitian}

Metodologi penelitian yang di mulai dari tanggal 06 November 2017- 27 Januari 2018 di PT. Chemco Harapan Nusantara cikarang khususnya pada departemen Gravity Die Casting pada saat kuliah magang industri dan dilanjutkan atau di perdalam pada laporan 
skripsi dari 05 Februari 2018- 27 Juli 2018. Metodologi berdasarkan flow proses untuk dapat menganalisa perancangan Fixture cutting Gate Master Cylinder type KVYG front dengan Solidwork Motion Analysis dengan 7 tahapan proses. Flow proses penelitian ditunjukkan oleh gambar 3.1.

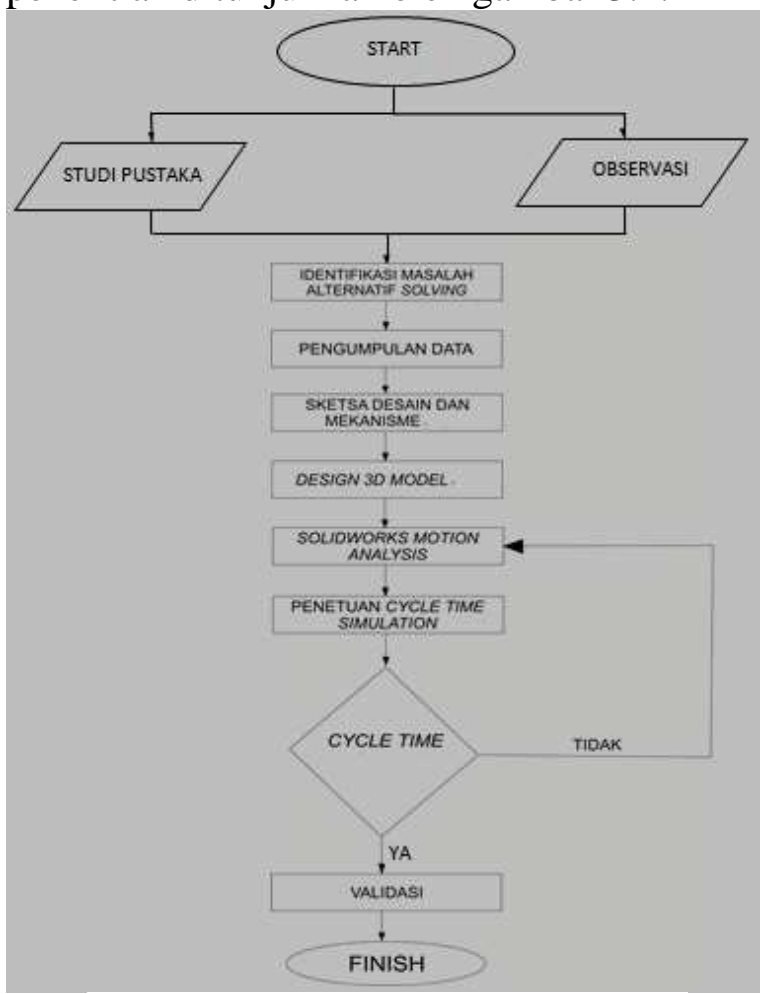

Gambar 3. Diagram Flow Process

\subsection{Identifikasi masalah}

Khusus untuk proses potong pada gate master cylinder type $K V Y G$ proses pemotongan masih tergolong manual dan proses ini memakan waktu yang relatif lama dengan data yang diperoleh menunjukkan untuk waktu pemotongan 40 pcs diperlukan waktu rata-rata 10 menit dan terdapat lost time proses 2,5 menit per 40 pcs sehingga kapasitas produksi kurang optimal. Lost time yang terjadi di proses ini merupakan salah satu akibat dari metode pemotongan gate master cylinder yang kurang efisien maka dengan merencanakan desain alat bantu pemotongan yang dapat menggantikan metode pemotongan sebelumnya.

\subsection{Pengumpulan data}

Proses pencarian data-data yang berkaitan dengan permasalahan yang ada dimana data yang didapat akan dijadikan sebagai acuhan dan validasi dalam proses perancangan dalam langkah pengujian. Seperti data produksi part Master Cylinder front type KVYG, cycle time proses potong, spesifikasi material, spesifikasi mesin potong dan sketsa part Master Cylinder front type KVYG.

\subsection{Sketsa desain Fixture dan mekanisme gerak}

Proses sketsa desain Fixture dimulai dari data-data observasi mengenai part Master Cylinder front type $K V Y G$ dan di sketsa untuk mendapatkan ukuran Fixture yang akan dirancang. Dilanjutkan dengan menentukan mekanisme gerak Fixture dengan memanfaatkan gerak pneumatik yang linier untuk proses pemotongan gate Master Cylinder front type KVYG yang efisien dan ergonomis.

\subsection{Desain 3D model dengan Solidworks}

Proses desain 3D model dengan menggunakan software Solidwoks merupakan tindak lanjut sketsa dan penentuan mekanisme gerak dari desain yang di rencanakan, desain $3 D$ model tersebut dapat di analisa gerak dan cycle time menggunakan Solidworks motion analysis.

\subsection{Solidworks motion analysis}

Simulasi gerak yang akan diciptakan adalah sebuah gerak animasi yang terdapat dalam fitur motion study. Dalam fitur motion study terdapat 2 menu pilihan, yaitu animation dan motion basic, dalam desain yang akan dilakukan, disini menggunakan pilihan motion study (animation), animasi ini sendiri dimaksudkan untuk memperlihatkan cara kerja Fixture Cutting gate Master Cylinder front type $K V Y G$.

\subsection{Penentuan cycle time proses}

Setelah melakukan desain dan menganalisa pada software Solidworks motion analysis dan menyelaraskan mekanisme yang sudah direncanakan pada tahap sebelumnya harus dapat menentukan cycle time proses yang diharapkan. Penentuan cycle time ini berdasarkan dengan parameter-parameter yang sudah ada di harapkan mendapatkan pendekatan simulasi yang efisien. 


\subsection{Validasi}

Proses validasi di dapatkan dari hasil analisis pada solidwork motion analysis dan cycle time yang di tentukan. Selain dari yang di atas didapatkan dari perhitungan-perhitungan yang sudah dilakukan seperti perhitungan gaya potong, estimasi produktifitas, shear stress dan perhitungan-perhitungan yang menunjang lainya.

\section{Hasil Dan Pembahasan}

\subsection{Alternatif Desain}

Pembuatan desain alat tidak lepas dari pembuatan alternatif desain pada umumnya pembuatannya melalui beberapa pertimbangan faktor keunggulan ataupun kelemahan pada alternatif desain yang sudah direncanakan. Selain hal tersebut diatas harus juga mempertimbangankan faktor ergonomis, fungsional, biaya, kekuatan mekanisme kerja dan safety. Alternatif desain yang telah dibuat akan dijelaskan sistem kerja serta kelebihan dan kekurangannya, yang selanjutnya desain dengan pembobotan desain (nilai tertinggi) yang akan dipilih dan akan dianalisis lebih lanjut. Kesimpulan dari hasil penilaian yang dilakukan dapat dipergunakan untuk memperbaiki desain awal, sehingga mendapatkan desain yang proporsionnal menurut fungsi, kekuatan, ergonomis, safety dan cost.

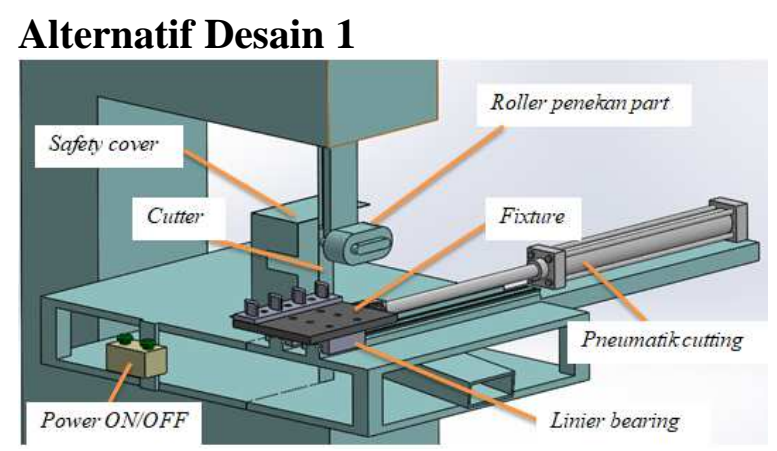

\section{Gambar 4. Desain Alternatif 1 Fixture gate MC Front KVYG}

Prinsip kerja

Pada alternatif desain 1 ini terdapat bagianbagian terdiri dari silinder pneumatik, linier bearing, Fixture, cutter, safety cover dan roller penekan part. mekanisme kerja yang linier pada proses potong dengan mengandalkan kerja pneumatik, pada proses kerja operator akan meletakkan atau memasangkan part pada Fixture yang ada dan akan menekan tombol ON pada awal langkah kerja. Jika sudah terjadi proses potong dan proses sudah selesai Fixture akan kembali pada posisi semula dengan part yang sudah selesai di potong, maka operator akan mengambil secara manual part tersebut dan akan di tata pada rak treatment. Proses tersebut akan di kerjakan secara berulangulang.

\section{1) Kekurangan}

a. Pengambilan part hasil masih manual.

b. Tidak adanya langkah kerja yang di lakukan secara bersamaan untuk mengurangi lost time.

c. Proses kerja yang kurang praktis.

\section{2) Kelebihan}

a. Biaya lebih murah.

b. Tingkat keamanan operator baik.

c. Pergerakan Fixture pada lintasan baik karena menggunakan linier guideway.

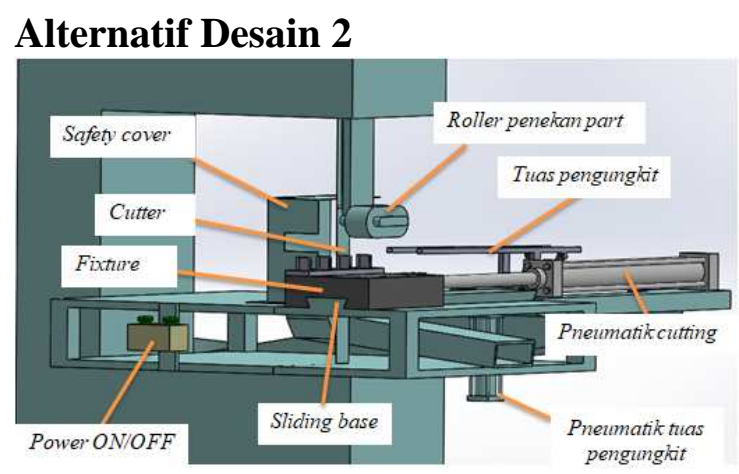

\section{Gambar 5. Desain Alternatif 2 Fixture gate MC Front KVYG}

Prinsip kerja

Prinsip kerja dari alternatif desain 2 ini hampir sama dengan alternatif desain 1 hanya saja pada desain ini sudah menggunakan pengambilan part secara otomatis yang dapat menjadikan desain ini lebih efisien dan lebih efektif dibandingkan dengan alternatif desain 1. Desain ini tidak menggunakan linier guideway malainkan menggunakan lintasan sliding dalam movement Fixture, pergerakan tetap sama dengan desain lain pada proses bolak-balik pada Fixture menggunakan pneumatik. 


\section{1) Kekurangan}

a. Tidak adanya langkah kerja yang di lakukan secara bersamaan untuk mengurangi lost time.

b. Movement Fixture kurang maksimal.

c. Biaya relatif tinggi.

d. Mekanisme dan kontruksi desain rumit.

\section{2) Kelebihan}

a. Pengambilan part hasil sudah otomatis.

b. Proses kerja yang praktis.

c. Tidak terjadi lost time penataan part.

\section{Alternatif Desain 3}

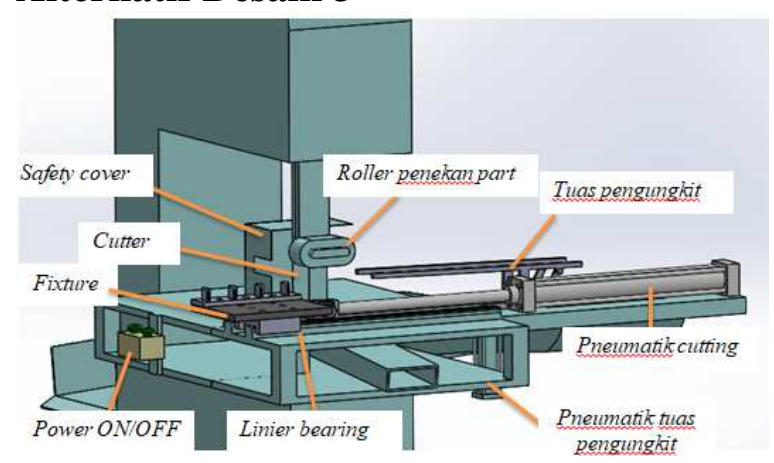

Gambar 6. Desain Alternatif 3 Fixture gate MC Front KVYG

Prinsip kerja

Pada alternatif desain 3 mekamisme kerja tersebut sama dengan memanfaatkan atau menggunakan gerak bolak-balik dari sistem kerja pneumatik dari melihat proses yang telah ada (prinsip dasar sama dengan aternatif desain sebelum-sebelumnya), yaitu dengan menghilangkan kontak langsung operator dengan benda/part. Saat proses pemotongan dan menghilangkan lost time yang terjadi saat proses arrange/penataan di rak treatment dikarenakan pada saat akhir proses potong pengambilan part hasil menggunakan sistem otomatis tidak lagi manual guna memaksimalkan dan meningkatan produktivitas di sub-potong.

\section{1) Kekurangan}

a. Biaya relatif tinggi.

b. Mekanisme dan kontruksi desain rumit.

\section{2) Kelebihan}

a. Pengambilan part hasil sudah otomatis.

b. Proses kerja yang praktis.

c. Tidak terjadi lost time penataan part.

d. Tingkat keamanan operator baik.

\subsection{Pembobotan Desain}

Dari beberapa alternatif desain akan dipilih alternatif desain yang dianggap memenuhi aspek fungsi, ergonomis, biaya, konstruksi, kekuatan dan safety. Langkah untuk penilaian daan pemilihan sebagai berikut :

Tabel 1. Bobot Penilaian (Nigel, 2000)

\begin{tabular}{llllllll}
\hline Kriteria & A & B & C & D & E & Jumlah & Bobot \\
\hline Ergonomis & 0 & 1 & 0,5 & 0 & 0,5 & 2 & 0,02 \\
Biaya & 0 & 0 & 0,5 & 0,5 & 1 & 2 & 0,02 \\
Konstruksi & 0,5 & 0,5 & 0 & 0 & 0,5 & 1,5 & 0,015 \\
Kekuatan & 1 & 0,5 & 1 & 0 & 1 & 3,5 & 0,035 \\
Safety & 0,5 & 0 & 0,5 & 0 & 0 & 1 & 0,01 \\
\multicolumn{5}{r}{ Jumlah nilai kriteria } & & 10 & 0,01 \\
\hline
\end{tabular}

\subsection{Penilaian Alternatif Desain}

Setelah melakukan proses pembobotan dari beberapa desain dengan masing-masing aspek maka selanjutnya akan dilakukan penilaian pada masing-masing desain. Dalam memberikan penilaian pada setiap alternatif desain di perlukan skala nilai untuk menentukan berapa nilai dari setiap aspek yang ada pada alternatif desain tersebut. Pada tabel 5.2 berikut akan di jelaskan batasan atau skala penilaian pada masing-masing alternatif desain.

\section{Tabel 2. Penilaian Masing - Masing Alternatif Desain}

\begin{tabular}{llllllll}
\hline \multirow{2}{*}{ Kriteria } & Bobot & \multicolumn{2}{l}{ Alternatif 1 } & \multicolumn{2}{l}{ Alternatif 2 } & \multicolumn{2}{l}{ Alternatif 3 } \\
\cline { 3 - 8 } & $\begin{array}{l}\text { Skor } \\
(\mathrm{n})\end{array}$ & $\begin{array}{l}\text { Nilai } \\
(\mathrm{u})\end{array}$ & $\begin{array}{l}\text { Skor } \\
(\mathrm{n})\end{array}$ & $\begin{array}{l}\text { Nilai } \\
(\mathrm{u})\end{array}$ & $\begin{array}{l}\text { Skor } \\
(\mathrm{n})\end{array}$ & $\begin{array}{l}\text { Nilai } \\
(\mathrm{u})\end{array}$ \\
$\mathbf{A}$ & 0,02 & 80 & 1,6 & 80 & 1,6 & 90 & 1,8 \\
$\mathbf{B}$ & 0,02 & 80 & 1,6 & 90 & 1,8 & 90 & 1,8 \\
$\mathbf{C}$ & 0,015 & 90 & 1,35 & 70 & 1,05 & 80 & 1,35 \\
D & 0,035 & 80 & 2,8 & 70 & 2,45 & 80 & 2,8 \\
E & 0,01 & 70 & 0,7 & 80 & 0,8 & 90 & 0,9 \\
\hline Jumlah & & & $\mathbf{8 , 0 5}$ & & $\mathbf{7 , 7}$ & & $\mathbf{8 , 6 5}$ \\
\hline
\end{tabular}

Keterangan :

$\mathrm{k}=$ presentase pembobotan dari setiap aspek (dari 100)

$\mathrm{n}=$ kualitas nilai dari setiap alternatif desain (dari 10)

$\mathrm{u}=$ nilai akhir dari setiap alternatif desain $=\mathrm{k}$ $\mathrm{x} \mathrm{n} / 100$

Rating $: 100=$ Sangat mudah

$$
\begin{aligned}
& 90=\text { Mudah } \\
& 80=\text { Sedang } \\
& 70=\text { Sulit }
\end{aligned}
$$


Cara sederhana untuk melakukan ini adalah dengan mempertimbangkan daftar urutanperingkat seolah-olah tujuan ditempatkan dalam posisi yang relatif penting, atau nilai, pada skala, katakanlah, 1 hingga 10 atau 1 hingga 100 (Nigel, 2000).

\subsection{Desain Terpilih}

Berdasarkan pembobotan di atas maka menurut teori (Nigel. 2000 : 155) dapat di pilih atau terpilih alternatif desain 3 yang proporsional berdasarkan aspek-aspek yang sudah di tentukan.

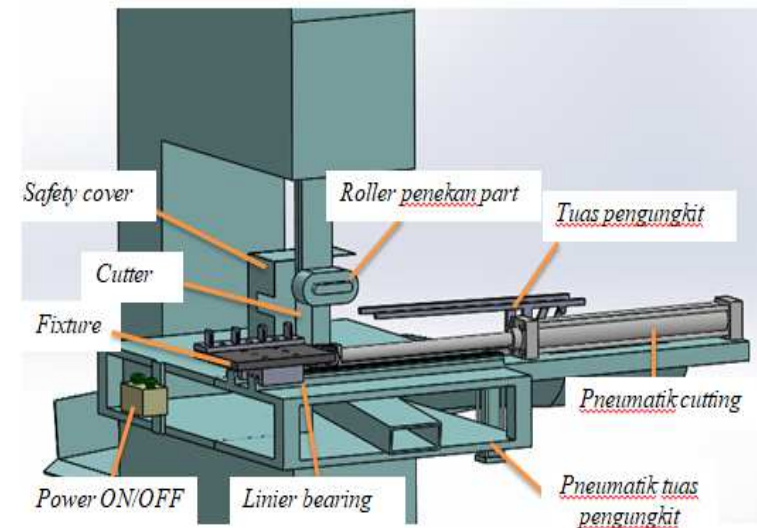

Gambar 7. Desain terpilih Fixture gate MC Front KVYG

\subsection{Perhitungan Gaya Pemotongan}

Berdasarkan Persamaan untuk mengetahui gaya penggergajian yang bekerja pada proses potong gate MC front KVYG dapat dihitung $F_{C}$ sebagai berikut:

$$
\begin{aligned}
& \sigma \mathrm{AC} 2 \mathrm{~B}=235[\mathrm{MPa}] \text { (Material properties) } \\
&=235 \times 10^{6}[\mathrm{~Pa}] \\
&=235 \times 10^{6}\left[\mathrm{~N} / \mathrm{m}^{2}\right] \\
& \mathrm{d}=25[\mathrm{~mm}] \\
&=25 \times 10^{-1}\left[\mathrm{~m}^{2}\right] \\
& \tau=0,8 \times \sigma \\
& F_{G}=a_{p} \cdot w_{G}, K(\mathrm{~N}) \\
& F_{\mathbb{C}}=a_{p} \cdot w_{C} \cdot K(\mathrm{~N}) \\
&=25 \mathrm{~mm} \times 2 \mathrm{~mm} \times 0.8 \times 235 \mathrm{Mpa} \\
&=9400[\mathrm{~N}]
\end{aligned}
$$

Berdasarkan analisis yang dilakukan maka dapat di ketahui besarnya gaya penggergajian $F_{c}=9400[\mathrm{~N}]$. Gaya penggerajian ini di butuhkan untuk menghitung gaya dorong silinder pneumatik.

\subsection{Perencanaan Silinder Pneumatik Fixture}

Perancangan ukuran silinder cutting yang berfungsi menarik atau mendorong Fixture pada proses potong berdasarkan gaya potong yang dibutuhkan untuk memotong part Master Cylinder type KVYG. Perhitungan besar beban Fixture yang akan digerakkan oleh silinder pneumatik menggunakan sofware solidworks dengan analisis evaluate mass properties berdasarkan jenis material yaitu AISI 1045 dan ukuran dimensi benda kerja. Hasil dari analisis evaluate mass properties per komponen akan mendapatkan berat dan massa total yang akan digunakan untuk menghitung diameter silinder yang sesuai agar dapat mendorong fixture dengan maksimal.

Tabel 3. Berat Komponen yang digerakkan Pneumatik Fixture

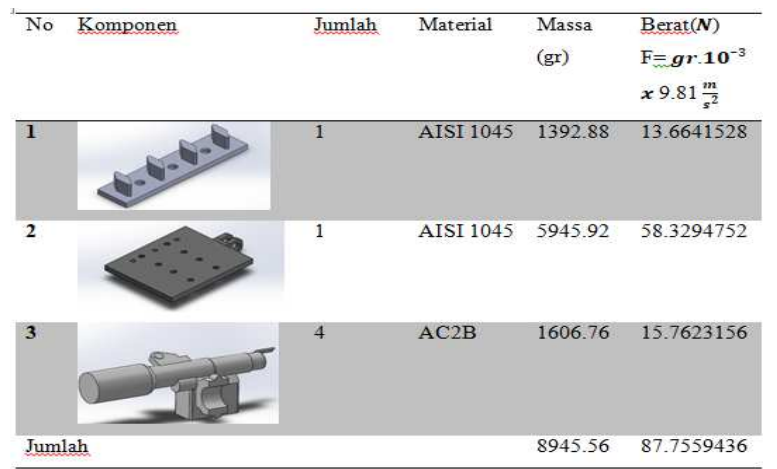

Berdasarkan analisis yang telah dilakukan yaitu menghitung gaya penggergajian dan berat komponen, besarnya gaya dorong $(\mathrm{F})$ silinder (piston) pneumatik dapat dihitung dengan menggunakan Persamaan (2.2).

$F_{\text {piston }}=\bar{F}_{C}+\bar{F}$

$$
\begin{aligned}
& =9400 \mathrm{~N}+87,7 \mathrm{~N} \\
& =9487,7 \mathrm{~N}
\end{aligned}
$$

Diameter silinder minimal yang didapat digunakan untuk mendorong piston pneumatik agar dapat mendorong fixture dan part MC Front KVYG dapat dihitung menggunakan Persamaan (2.7).

$\frac{\pi}{4} d^{2}=\frac{B}{2}$

Berdasarkan perhitungan yang telah dilakukan, besarnya $\mathrm{F}_{\text {piston }}$ adalah 9487,7 N. Apabila data ini dimasukkan kedalam Persamaan 2.7 maka : 


$$
\begin{aligned}
& \mathrm{d}_{\text {bore }}=\sqrt{\frac{4 \pi F}{\pi \times p}} \\
& =\sqrt{\frac{4 \times 9487 \pi[\mathrm{N}]}{\pi \times 700000\left[\frac{\mathrm{N}}{\mathrm{m}^{\mathrm{I}}}\right.}} \\
& =0,131[\mathrm{~m}] \\
& \mathrm{d}_{\text {bore }}=131[\mathrm{~mm}]
\end{aligned}
$$

Menurut Tabel apabila tekanan pneumatik yang digunakan adalah 0,7 $\mathrm{MPa}$, maka silinder pneumatik dengan dimensi $\mathrm{d}_{\text {bore }}=$ $140 \mathrm{~mm}$ dan $\mathrm{d}_{\mathrm{rod}}=36 \mathrm{~mm}$ memiliki gaya dorong sebesar 10800 N. Silinder pneumatik ini dapat digunakan karena gaya dorong yang dihasilkan $(10800 \mathrm{~N})$ lebih besar dari gaya total yang dibutuhkan untuk melakukan proses penggergajian $(9487,7 \mathrm{~N})$.

Tabel 4. Gaya piston silinder berbagai ukuran pada tekanan $0,2-10$

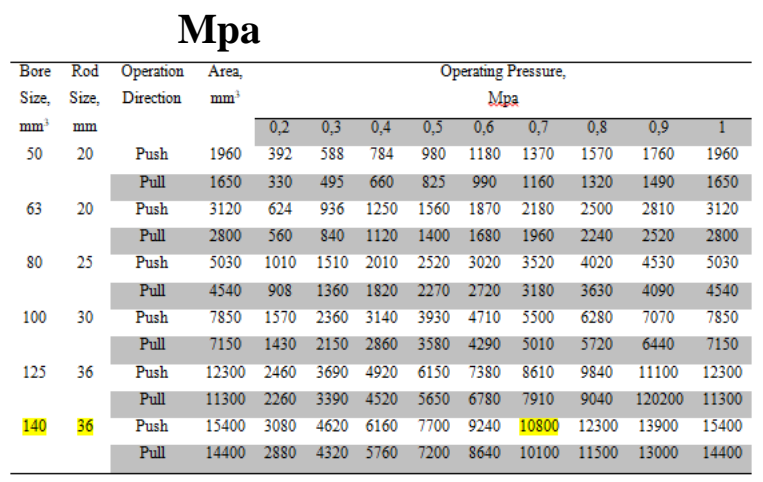

\subsection{Perhitungan konstruksi Fixture}

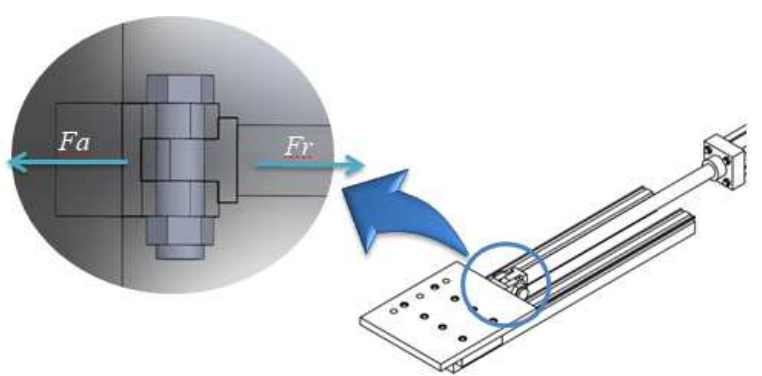

Gambar 8. Tegangan geser pin Fixture

$$
\begin{aligned}
\sigma & =\frac{F}{A} \\
A & =\frac{F a+F r}{\sigma} \\
& =\frac{92,3 \times 10^{3}[N]+87,7[N]}{734,32 \times 10^{6}\left[N / m^{2}\right]} \\
& =1,256 \times 10^{-4}\left[\mathrm{~m}^{2}\right]
\end{aligned}
$$

Luas area pin fixture dapat diketahui dengan persamaan (2.4) diatas sebesar $1,256 \times 10^{-4}$ $\left[\mathrm{m}^{2}\right]$ dan untuk menghitung diameter pin minimal (yang diijinkan) pada perhitungan berikutnya.

$\mathrm{A}=\frac{\pi}{4} \mathrm{D}^{2}$

Dpin $=\sqrt{\frac{4 \times 1,256 \times 10^{-4}\left[m^{2}\right]}{\pi}}$

Dpin $=0,0126[\mathrm{~m}]$

Dpin $=12,6[\mathrm{~mm}]$

Besarnya diameter pin fixture yang dapat diketahui dengan perhitungan diatas sebesar $12,6[\mathrm{~mm}]$ yang dapat dikatakan aman untuk sebuah konstuksi.

\subsection{Perencanaan Silinder Pneumatik Pengungkit}

Perancangan untuk silinder pengungkit berfungsi untuk mengangkat beban part Master cylinder yang sudah melalui proses potong, beban yang ada pada proses pengungkit atau pengambilan part ada seperti pada tabel 5.2 di bawah.

Perhitungan besar beban yang akan di angkat oleh silinder pneumatik adalah menggunakan sofware solidworks dengan analisis evaluate mass properties pada desain dengan material sesuai yaitu AISI 1045 dan ukuran dimensi benda kerja mendekati sebenarnya.
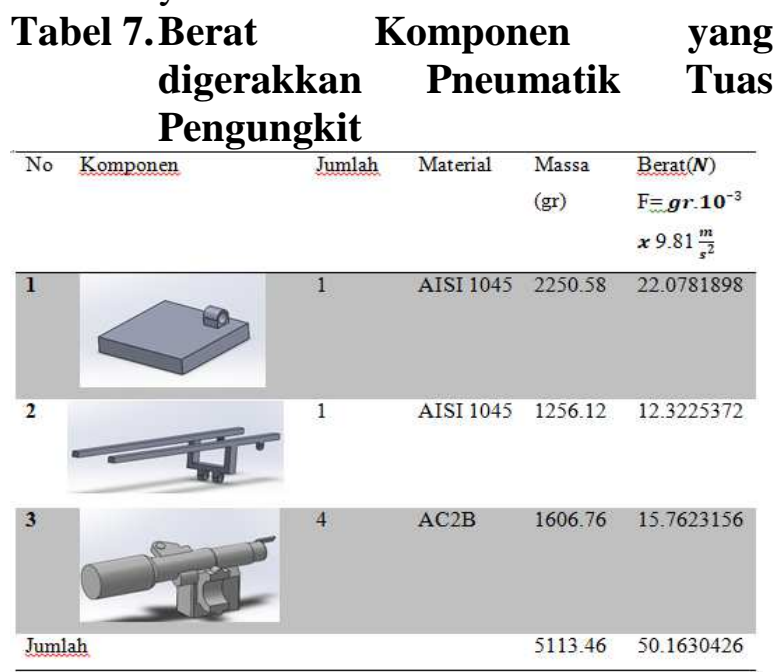

Berdasarkan tabel 7 menghasilkan berat beban keseluruhan yang dapat diangkat oleh pengungkit atau pengambil part after cutting, serta dapat di hitung spesifikasi pneumatik yang dapat mengangkat part dengan sempurna. Berikut berdasarkan persamaan 2.4 adalah perhitungan untuk diameter silinder pneumatik. 


\subsection{Perhitungan Silinder Pengungkit}

$$
\begin{aligned}
\mathrm{P} & =\frac{D}{A} \\
\mathrm{~A} & =\frac{F}{P} \\
& =\frac{50 ; 1[\mathrm{~W}]}{600000\left[\mathrm{~N} / \mathrm{m}^{\mathrm{s}}\right]} \\
& =0,0000833\left[\mathrm{~m}^{2}\right]
\end{aligned}
$$

Hasil dari perhitungan diatas dengan menggunakan persamaan (2.4) maka luas area yang sudah didapatkan sebesar $0,0000833\left[\mathrm{~m}^{2}\right]$.

\subsection{Perhitungan Diameter Silinder}

\section{Fixture}

$$
\begin{aligned}
\frac{\pi}{4} d & =\frac{F}{F} \\
\text { Dbore } & =\sqrt{\frac{4 \pi F}{\pi \times p}} \\
& =\sqrt{\frac{4 x 30,1[\mathrm{~N}]}{\pi x 600000\left[\frac{\mathbb{N}}{m} d\right.}} \\
& =0,0103[\mathrm{~m}]
\end{aligned}
$$

Dbore $=10,3[\mathrm{~mm}]$

Berdasarkan hasil perhitungan di atas didapatkan diameter silinder pneumatik take out yang di butuhkan untuk dapat mengangkat part yang mempunyai gaya sebesar 50,1 [N] adalah 10,3 [mm], namun ukuran tersebut tidak ada di pasaran maka diameter silinder dipilih diameter 10 [mm] dan panjang stroke 100 [mm].

\subsection{Estimasi Kapasitas Produksi}

\section{a. Estimasi Produktivitas Tanpa Fixture}

Data yang diperoleh menunjukkan untuk waktu produksi 40 pcs Master Cylinder front KVYG diperlukan waktu rata-rata 10 menit. beberapa lost yang terjadi dalam kegiatan bekerja pada PT. Chemco Harapan Nusantara, diantaranya:

1) Istirahat, sholat dan makan 50 menit.

2) Break time 10 menit.

3) Breafing pagi.

4) Pembagian APD.

5) Cek mesin sesuai SOP.

6) Proses potong, cek visual, menata part kedalam rak treatment.

7) Waktu ketoilet.

8) Lost time proses 2,5 menit per 40 pcs

Jika dalam satu hari kerja 8 jam dengan waktu efektif 7 jam dan dikurangi dengan lost time yang terjadi maka waktu proses selama 4,2 jam, Berdasarkan beberapa lost time diatas diasumsikan total lost time sebesar $40 \%$. Dengan perhitungan produktivitas tanpa Fixture seperti dibawah ini:

$=\frac{\text { waktu efektif bekerja } \times(100 \%-\text { lost tbme })}{\text { rata waktu proses } / 40 p e s}$ $=\frac{7 \mathrm{jam} \times 60 \%}{10 \text { menit } / 1 \mathrm{box}} \times 40 \mathrm{pcs}$

$=\frac{4,2 \text { jam }}{10 \text { menit } / 1 \text { box }} \times 40$ pcs

$=\frac{252 \text { menit }}{10 \text { menit } / 1 \text { box }} \times 40$ pcs

$=25$ box $\times 40 \mathrm{pcs}$

$=1000 \mathrm{pcs}$

b. Estimasi Produktivitas Dengan Menggunakan Fixture

Data yang diperoleh menunjukkan untuk waktu produksi 40 pcs Master Cylinder front KVYG diperlukan waktu rata-rata 7 menit. beberapa lost yang terjadi dalam kegiatan bekerja pada PT. Chemco Harapan Nusantara, diantaranya:

1) Istirahat, sholat dan makan 50 menit.

2) Break time 10 menit.

3) Breafing pagi.

4) Pembagian APD.

5) Cek mesin sesuai SOP.

6) Proses potong, cek visual, menata part kedalam rak treatment.

7) Waktu ketoilet.

Jika dalam satu hari kerja 8 jam dengan waktu efektif 7 jam dan dikurangi dengan lost time yang terjadi ( dengan hilangnya lost time saat penataan) maka waktu proses selama 5,6 jam, Berdasarkan beberapa lost time diatas diasumsikan total lost time sebesar 20\%. Dengan perhitungan produktivitas dengan menggunakan Fixture seperti dibawah ini:

$$
\begin{aligned}
& =\frac{\text { waktu ef ektif bekerja } \times(100 \%-\text { lost time })}{\text { rata waktu proses } / 40 \text { pcs }} \\
& =\frac{7 \text { jan } \times 30 \%}{7 \text { menit } / 1 \text { box }} \times 40 \text { pos } \\
& =\frac{5.6 \text { jam }}{7 \text { menit } / 1 \text { box }} \times 40 \text { pcs } \\
& =\frac{336 \text { menit }}{7 \text { menit } / 1 \text { box }} \times 40 \text { pcs } \\
& =48 \text { box } \times 40 \text { pcs } \quad=1920 \text { pos }
\end{aligned}
$$




\subsection{Solidworks Motion Analysis}

Dibawah ini merupakan pengujian yang dilakukan pada menu Event Based Motion Analysis di software Solidworks, dengan memasukkan parameter waktu dan besarnya nilai gerakan linear motor. Waktu pergerakan setiap komponen otomasi yang telah ditentukan digunakan sebagai input dalam pembuatan simulasi. Output dari pembuatan simulasi ini yaitu video simulasi dengan pergerakan desain sesuai dengan perhitungan waktu yang telah ditentukan.

Simulasi ini berfungsi untuk membantu dalam memvisualisasikan atau mempresentasikan bagaimana pergerakan yang melalui pendekatan proses yang sebenarnya dari desain yang dibuat. Ouput dari pengujian ini adalah simulasi gerakan dalam bentuk video dan cycle time.

Pengujian dilakukan dengan simulasi solidworks dengan input data waktu yang di peroleh dari estimasi proses potong sebelumnya yaitu menghilangkan proses penataan pada proses yang menjadi sumber lost time sebesar 5 detik/pcs dan mengahasilkan waktu proses keseluruhan 15 detik/pcs, hal ini menjadi acuan dalam input waktu proses improvment pada solidworks motion analysis. Output yang dihasilkan pada simulasi ini berupa waktu yang yang sudah di kalkulasi setiap proses menjadi 10 detik/pcs. Pengujian ini menjadi suatu validitas dari perancangan fixture pemotongan gate Master Cylinder front KVYG.

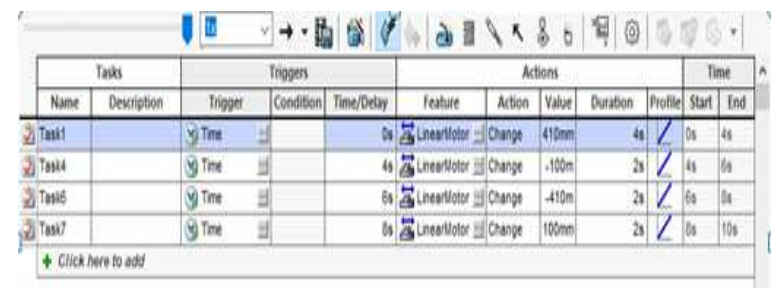

Gambar 9 Input Data Motion Analysis

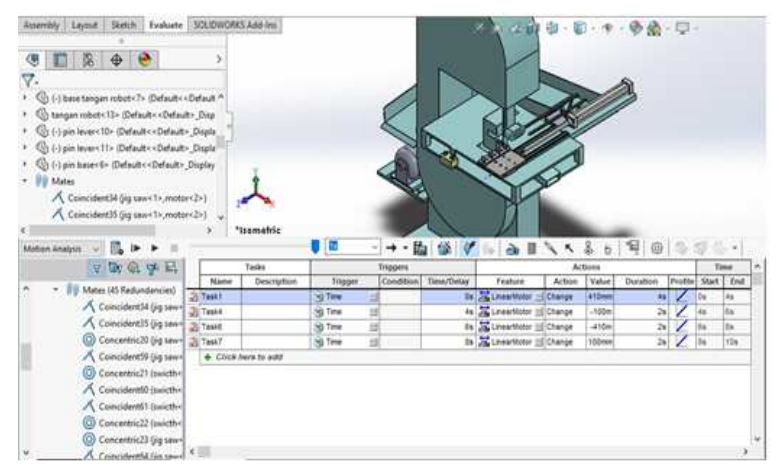

Gambar 10 Visualisasi Motion Analysis

Hasil dari beberapa inputan yang di lakukan pada Solidworks Motion Analysis di dapatkan kalkulasi waktu keseluruhan untuk 1 proses pemotongan yaitu sebesar $10 \mathrm{detik} / \mathrm{pcs}$ seperti gambar 11 dibawah ini.

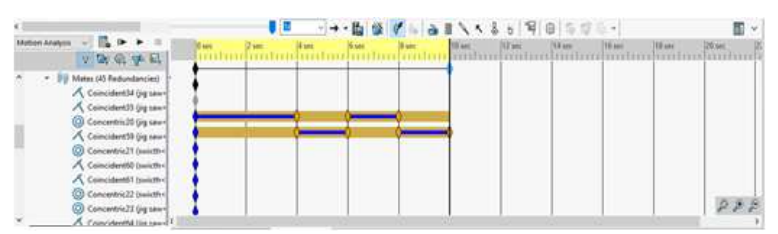

\section{Gambar 11 Output Motion Analysis}

Pengujian ini bertujuan mengoptimalkan waktu proses pemotongan yang akhirnya akan meningkatkan kapasitas produksi melalui Simulasi Desain Fixture Menggunakan Solidworks Motion Analysis Berdasarkan hasil analisis perhitungan yang di lakukan pada analisis di atas maka di peroleh perbandingan hasil dari proses sebelumnya seperti pada tabel 5.6 di bawah.

\subsection{Mekanisme Kerja Fixture}

Berikut gambaran layout proses manual dan proses Otomasi yang dapat menghilangkan proses penataan sebagai titik lost time tertinggi di proses potong manual.

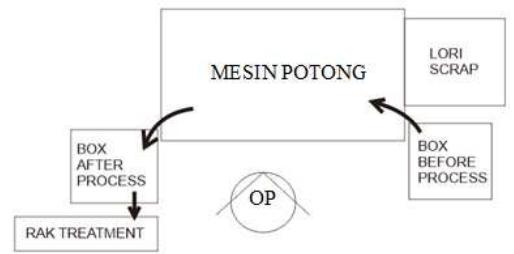

Gambar 12 Layout Proses Potong Manual 




Gambar 13 Layout Proses Perencanaan Otomasi

Proses potong part Master cylinder front $K V Y G$ sesuai SOP yang telah ada dimulai dari pengecekan visual secara $100 \%$ dan kemudian di tata di rak treatment apabila part dinyatakan $\mathrm{OK}$, proses potong manual dengan cara mengambil part di box yang sudah di siapkan di area after proses dan di pegang dengan tangan lalu di potong di mesin potong secara manual. Hal ini di rasa penulis terlalu bahaya karena operator ber sentuhan langsung dengan part.

Berdasarkan beberapa permasalahan diatas, memberikan perencanaan desain otomasi produksi pada pemotongan gate Master cylinder front $K V Y G$ Di Departemen Gravity Die Casting untuk mengurangi risiko - risiko yang mungkin timbul dari proses potong seperti diatas dan untuk meningkatkan kuantitas part yang telah dipotong. Berikut adalah konsep desain otomasi produksi pada pemotongan pemotongan gate Master cylinder front $K V Y G$ dan cara kerjanya.

Prinsip dasar dari Fixture ini menggunakan prinsip linier recriprocating dengan menggunakan lintasan linier guideway untuk lintasan maju mundurnya. Fixture di gerakkan oleh Pneumatik yang ada di pangkal proses potong, pneumantik mendapat supply dari udara yang sudah ada di sub potong. Otomatisasai di dapatkan dari pemasangan limit switch yang ada di awal dan akhir proses maju mundur dan proses kerja di awali dengan menekan tombol ON. Model mekanis maju mundur di asumsi dari proses manual yang dapat di kembangkan di proses Otomasi yang di rencanakan dapat meningkatkan produktifitas dan meningkatkan efisiensi kerja potong gate Master cylinder front KVYG menjadi 10,5 detik/pcs, karena dalam proses Otomasi ini dapat menghilangkan waktu yang hilang Dengan Rata-Rata 5 Detik/Pcs.
Tabel 8 Perbandingan Kapasitas Produksi

\begin{tabular}{lccc}
\hline NO & Variabel & Tanpa Fixture & Estimasi Dengan \\
& & & Fixture \\
\hline $\mathbf{1}$ & Rata-rata lost time proses & 5 detik & 0 detik \\
$\mathbf{2}$ & Waktu proses & 15 detik/pcs & 10,5 detik $/ \mathrm{pcs}$ \\
$\mathbf{3}$ & Kapasitas produksi & $1000 \mathrm{pcs} / \mathrm{shift}$ & $1920 \mathrm{pcs} / \mathrm{shift}$ \\
\hline
\end{tabular}

Produktivitas Akan Lebih Optimal Apabila Cycle Time Proses Potong Otomatis, Namun Di Perencanaan Desain Ini Di Asumsikan Cycle Time Masih Sama Dengan Proses Potong Manual Hanya Saja Proses Otomatis Masih Sebatas Menghilangkan Proses Penataan Pada After Procees Potong.

Maka Dengan Perencanaan Desain Ini Akan Meningkatnkan Jumlah Target Pencapaian Harian Dan Peningkatan Intensitas Proses Potong Yang Di Perencanaan Desain Ini Akan Meningkatkan Produktivitas Sebesar 90 \% Dan Kualitas Produk Part Master Cylinder Front Kvyg.

\section{Kesimpulan}

Kesimpulan Dari Analisis "Optimasi Waktu Pemotongan Gate Master Cylinder Front Kvyg Dengan Simulasi Desain Fixture Menggunakan Solidworks Motion Analysis" Di Departement Gravity Die Casting Industri Brake System Cikarang Yaitu,

1) Hasil Perancangan Desain Desain Fixture Gate Master Cylinder Front Kvyg Dengan Otomasi Pneumatik Dapat Di Rekomendasikan Sebagai Alat Bantu Potong Part Master Cylinder Front Kvyg Dan Dapat Di Kembangkan Untuk Part Master Cylinder Front Type Lainnya Yang Di Produksi Oleh Pt Chemco Harapan Nusantara.

2) Tingkat Produktivitas Berdasarkan Rancangan Estimasi Hasil Proses Produksi Dari Pemotongan Manual Menghasilkan Sejumlah Output Produksi Aktual Rata-Rata 772 Pcs Namun Secara Teoritis Rata-Rata 1000 Pcs Setelah Adanya Perancangan Alat Bantu Potong Part Master Cylinder Front Type Kvyg Dengan Otomasi Pneumatik Tingkat Produktivitasnya Naik Menjadi 1920 Pcs Dan Untuk Cycle Time Pemotongan Dapat Dipersingkat Dari 15 Detik/Pcs Menjadi 10,5 Detik/Pcs. 
3) Berdasarkan Analisis Yang Dilakukan Maka $F_{C}=9400[\mathrm{~N}]$ Dan Gaya Piston $\mathrm{F}_{\text {piston }}$ Yang Di Butuhkan Untuk Memotong Part Mc Type Kvyg Front Sebesar 9487,7 [N] Dan Terdapat 2 Pneumatik Yaitu Pneumatik Fixture Yang Berdiameter $\quad \mathrm{D}_{\text {rod }}=36$ [Mm]Serta Pneumatik Tuas Pengungkit (Take Out) Berdiameter 10,3 [Mm].

\section{Daftar Pustaka}

- Abouhenidi Hamad Mohammed. 2014. "Jig and Fixture Design". St. Mary's University.

- Abedini Vahid, et al., 2103. "Automated process planning system: A new method for setup planning and a mathematical model for fixture design”. Faculty of Mechanical Engineering, Babol Noshirvani University of Technology, Iran

- Bandung Institute of Technology- Swiss Project on Polytechnic of Mechanic. 1987. Tool Design. Bandung.

- Chemco. 2017. Handbook Gravity Die Casting. Chemco Harapan Nusantara, Cikarang, Jawa Barat.

- Cross Nigel. 2000. Engineering Design Methods Strategies for Product Design. THIRD EDITION, The Open University, Milton Keynes, $U K$.

- Dassault System 3D Experience Company. 2017. "Solidworks Simulation Suite Drive Innovation With 3D Enginners Solution". Dassault Sytemes Solidworks Corporation.

- Dewantara Alex Bagus dan Kholil Muhammad. 2015. "Sistem Otomasi Sebagai Upaya Perbaikan Kualitas Dengan Metode Spc Pada Line Finishing”. Teknik Industri Universitas Mercu Buana, Jakarta.

- Grover, M., 2002. Automation, Production Systems, and ComputerIntegrated Manufacturing. Tsinghua, Department of Industrial Engineering, Tsinghua University.
- Hauge BS., et al. 2000 "Reliabilitycentered maintenance on the Space Shuttle Program" United Space Alliance, Cape Canaveral, FL, USA.

- Hasan MF., 2016. "Analysis of Mechanical Behavior and Microstructural Characteristics Change of ASTM A-36 Steel Applying Various Heat Treatment". Department of Industrial Engineering and Management, Khulna University of Engineering and Technology, Khulna-9203, Bangladesh.

- Porankiewicz Bolesław et. al. 2011. "Main And Normal Cutting Forces By Machining Wood Of Pinus Sylvestris".: Westinghouse Electric Company European LWR Fuel Business, Luleå University of Technology.

- Sofyan Bondan T. and Kartika Ria. 2005. "Department of Metallurgy and Materials, Faculty of Engineering, University of Indonesia". Kampus UI Depok 16424: Indonesia.

- Subhan Muhammad, Satmoko Ari. 2016. "Penentuan Dimensi Dan Spesifikasi Silinder Pneumatik Untuk Pergerakan Tote Iradiator Gamma Multiguna Batan". Pusat Rekayasa Fasilitas Nuklir (PRFN) BATAN

- Septiawan Dimas Budi and Bekti Rudy. 2016. "Analysis Of Project Construction Delay Using Fishbone Diagram At Pt. Rekayasa Industri”. Institute Teknologi Bandung, Indonesia. 